\title{
KEDUDUKAN POTONGAN PAJAK PRIBADI TERHADAP ZAKAT YANG TELAH DIBAYARKAN
}

\author{
Agus Budi Yuwono \\ Magister Hukum Universitas Semarang
}

\begin{abstract}
ABSTRAK
Tujuan penelitian ini adalah untuk membahas dan menganalisa kedudukan potongan pajak pribadi terhadap zakat yang telah dibayarkan. Permasalahan yang dibahas dalam penelitian ini adalah bagaimana kedudukan potongan pajak pribadi terhadap zakat yang telah dibayarkan berdasarkan UU Nomor 23 Tahun 2011 tentang Zakat dan permasalahan yang timbul atas potongan pajak pribadi terhadap zakat yang telah dibayarkan. Metode pendekatan yang digunakan dalam penelitian ini adalah yuridis normatif Hasil penelitian menunjukkan bahwa kedudukan potongan pajak pribadi terhadap zakat yang telah dibayarkan berdasarkan UU Nomor 23 Tahun 2011 tentang Pengelolaan Zakat adalah bahwa zakat yang telah dibayarkan akan mengurangi penghasilan bruto atas pajak pribadi, bukan mengurangi nominal pajak pribadi. Permasalahan yang timbul atas potongan pajak pribadi terhadap zakat yang telah dibayarkan adalah masih kurangnya pengetahuan masyarakat terkait adanya peraturan mengenai pemotongan pajak pribadi atas zakat yang dibayarkan. Hal ini dikarenakan kurangnya sosialisasi mengenai peraturan tersebut terhadap masyarakat. Untuk mengatasi permasalahan tersebut, perlu upaya mensosialisasikan mengenai zakat sebagai pengurang penghasilan bruto yang dilakukan secara terintegrasi bagi dari lembaga keagamaan maupun lembaga perpajakan.
\end{abstract}

Kata kunci : pemotongan pajak pribadi; zakat; penghasilan 


\title{
POSITION OF PERSONAL TAX CUTTING TOWARD ZAKAT THAT HAS BEEN PAID
}

\author{
Agus Budi Yuwono \\ Master of Law, University of Semarang
}

\begin{abstract}
The purpose of this research is to discuss and analyze the position of personal tax deductions on zakat that has been paid. The problem discussed in this study is how the position of personal tax deductions for zakat that has been paid based on Law Number 23 of 2011 concerning Zakat and problems arising from personal tax deductions for zakat that has been paid. The method of approach used in this research is normative juridical. The results of the study show that the position of personal tax deduction on zakat that has been paid based on Law Number 23 Year 2011 on Management of Zakat is that zakat that has been paid will reduce the gross income of personal tax, not reduce the nominal tax personal. The problem that arises from the deduction of personal tax on zakat that has been paid is the lack of public knowledge related to the existence of regulations regarding the deduction of personal tax on zakat paid. This is due to the lack of socialization regarding these regulations to the public. To overcome this problem, it is necessary to socialize about zakat as a reduction in gross income which is carried out in an integrated manner for religious institutions and taxation institutions.
\end{abstract}

Keywords: personal tax deduction; zakat; income 


\section{A. Pendahuluan}

Zakat dan pajak adalah sama-sama mempunyai fungsi pemungutan. Pada zakat, fungsi pemungutannya dapat dilakukan oleh terkena kewajiban membayar zakat dan dapat langsung disalurkan kepada orang yang berhak menerimanya atau dilakukan oleh suatu badan atau lembaga resmi (BAZ atau LAZ) yang dibentuk untuk memungut zakat serta mendistribusikan kepada delapan golongan yang berhak menerima zakat. Sedangkan dalam pajak, fungsi pemungutannya dilakukan oleh negara melalui Dirjen Pajak. ${ }^{1}$

Permasalahan yang melibatkan penduduk miskin sangat kompleks, sehingga sulit untuk diselesaikan. Kemiskinan bukan hanya disebabkan oleh faktor alamiah saja, namun faktor pemerataan pembangunan juga memberikan pengaruh terhadap masalah ini. Salah satu solusi yang ditawarkan oleh ekonomi Islam untuk menyelesaikan masalah ini, yaitu dengan pemberdayaa masyarakat

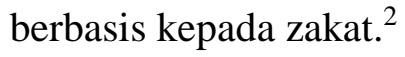

Saat ini undang-undang menjadikan zakat sebagai salah satu faktor pengurang penghasilan bruto wajib pajak orang pribadi dan badan usaha yang dimiliki oleh seorang muslim didalam menentukan besarnya penghasilan kena pajak. Hal ini diharapkan dapat meminimalkan beban ganda yang dipikul oleh umat Islam sebagai wajib pajak dan muzzaki. Pola perlakuan tersebut adalah yang optimal untuk mengelola dan mengakomodasi zakat dan pajak, yang kenyataannya kedua hal tersebut merupakan dua sumber pemungutan yang sama-sama dihimpun dari masyarakat. Apabila upaya pengelolaan dan pengakomodasian ini telah berjalan baik, dapat memberikan suatu efek yang produktif dalam pembangunan nasional. Jika dilihat dari fungsi dasarnya membayar zakat bisa disamakan nilainya dengan membayar pajak yakni samasama dimaksudkan untuk melaksanakan kewajiban yang bertujan untuk kemaslahatan umat dan bangsa.

\footnotetext{
${ }^{1}$ Sri Andriani, Zakat sebagai Pengurang Pajak Penghasilan Pada Badan Amil Zakat, JRAK, Vol. 4 No.1 Februari 2013, hlm.14

2 Abdul Aziz, Pendayagunaan Zakat Sebagai Upaya Pengentasan Kemiskinan, Jurnal Ius Constituendum Vol 1 No 1, Magister Hukum Universitas Semarang, 2016, Semarang, hlm 85.
} 
Sebagai umat muslim dan warga negara yang baik tentulah kewajiban membayar zakat dan pajak harus dipenuhi. Dengan adanya ketentuan bahwa zakat sebagai pengurang pajak, maka diharapkan kesadaran umat muslim untuk membayar zakat sehingga potensi zakat yang ada dapat terealisasi. Warga Negara Indonesia yang beragama islam berkewajiban mengeluarkan zakat sebagai realisasi pelaksanaan perintah agama dan berkewajiban pula membayar pajak sebagai realisasi ketaatan kepada pemerintah yang juga diwajibkan oleh agama. Zakat nantinya akan didistribusikan kepada 8 asnaf yang tercantum dalam Al Qur'an, sedangkan pajak akan masuk kepada APBN yang akan digunakan untuk kepentingan rakyat dan membangun fasilitas umum.

Berdasarkan uraian di atas, penulis tertarik untuk melakukan penelitian dengan judul : "KEDUDUKAN POTONGAN PAJAK PRIBADI TERHADAP ZAKAT YANG TELAH DIBAYARKAN DALAM KAJIAN UU NOMOR 23 TAHUN 2011 TENTANG PENGELOLAAN ZAKAT”.

\section{B. Perumusan Masalah}

1. Bagaimana kedudukan potongan pajak pribadi terhadap zakat yang telah dibayarkan berdasarkan UU Nomor 23 Tahun 2011 tentang Zakat?

2. Bagaimana permasalahan yang timbul atas potongan pajak pribadi terhadap zakat yang telah dibayarkan dan bagaimana solusinya?

\section{Metode Penelitian}

Metode pendekatan yang digunakan dalam penelitian ini adalah normatif, sehingga data yang digunakan adalah data sekunder. Metode pengumpulan data dilakukan melalui studi kepustakaan, sedangkan metode analisis data menggunakan analisis kualitatif.

\section{PEMBAHASAN}

\section{Kedudukan Potongan Pajak Pribadi Terhadap Zakat Yang Telah dibayarkan berdasarkan Uu Nomor 23 Tahun 2011 Tentang Zakat}

Zakat yang dapat mengurangi Penghasilan Kena Pajak adalah zakat yang diserahkan atau dibayar kepada amil zakat yang disahkan oleh Pemerintah. Hal ini dapat dilihat pada Pasal 9 ayat(1) huruf g UndangUndang Nomor 36 Tahun 2008 yang menyatakan bahwa untuk menentukan 
besarnya Penghasilan Kena Pajak bagi Wajib Pajak dalam negeri dan bentuk usaha tetap tidak boleh dikurangkan kecuali zakat yang diterima oleh Badan Amil Zakat atau Lembaga Amil Zakat yang dibentuk atau disahkan oleh pemerintah.

Lebih lanjut pada Pasal 2 Peraturan Pemerintah Nomor 18 Tahun 2009 tentang Bantuan atau Sumbangan Termasuk Zakat atau Sumbangan Keagamaan yang Sifatnya Wajib yang Dikecualikan Dari Objek Pajak Penghasila menyebutkan bahwa yang dimaksud zakat adalah zakat yang diterima oleh Badan Amil Zakat atau Lembaga Amil Zakat yang dibentuk atau disahkan oleh Pemerintah dan penerima zakat yang berhak.

Pasal 22 Undang-Undang Nomor 23 Tahun 2011 tentang Pengelolaan Zakat menyebutkan bahwa zakat yang dibayarkan oleh muzaki kepada BAZNAS atau LAZ dikurangkan dari Penghasilan Kena Pajak. Demikian halnya dalam Pasal Peraturan Pemerintah Nomor 60 Tahun 2010 menyebutkan bahwa apabila pengeluaran untuk zakat atau sumbangan keagamaan yang sifatnya wajib tidak dibayarkan kepada Badan Amil Zakat atau Lembaga Amil Zakat tidak dapat dikurangkan dari penghasilan bruto.

Pasal 1 ayat(1) huruf a dan Pasal 2 Peraturan Menteri Keuangan Nomor 254/PMK.03/2010 tentang Tata Cara Pembebanan Zakat atau Sumbangan Keagamaan yang Sifatnya Wajib yang dapat Dikurangkan dari Penghasilan Bruto, juga mengatur bahwa zakat yang dapat dikurangkan pada Penghasilan Kena Pajak adalah zakat atas penghasilan yang dibayarkan oleh Wajib Pajak orang pribadi pemeluk agama Islam dan/atau oleh Wajib Pajak badan dalam negeri yang dimiliki oleh pemeluk agama Islam kepada Badan Amil Zakat atau Lembaga Amil Zakat yang dibentuk atau disahkan oleh Pemerintah dan Badan Amil Zakat atau Lembaga Amil Zakat yang dibentuk berdasarkan Undang-undang yang mengatur tentang pengelolaan zakat dan perubahannya. Selanjutnya pada Pasal 4 ayat(2) menyatakan bahwa apabila pengeluaran untuk zakat atau sumbangan keagamaan yang sifatnya wajib tidak dibayarkan kepada Badan Amil Zakat atau Lembaga Amil Zakat, atau lembaga 
keagamaan sebagaimana dimaksud dalam Pasal 1 ayat(1), pengeluaran tersebut tidak dapat dikurangkan dari penghasilan bruto.

Berdasarkan ketentuan Pasal 3 Peraturan Direktur Jenderal Pajak Nomor PER-6/PJ/2011, zakat tidak dapat dikurangkan dari penghasilan bruto apabila :

1. tidak dibayarkan oleh Wajib Pajak kepada badan amil zakat; lembaga amil zakat; atau lembaga keagamaan, yang dibentuk atau disahkan Pemerintah; dan/atau

2. bukti pembayarannya tidak memenuhi ketentuan sebagaimana dimaksud dalam Pasal 2 ayat (2).

Berdasarkan ketentuan tersebut, diketahui ada syarat-syarat tertentu agar zakat dapat mengurangi penghasilan bruto salah satunya adalah bahwa zakat wajib dibayarkan kepada badan amil zakat yang dibentuk dan disahkan oleh pemerintah.

Pemotongan pajak pribadi oleh wajib pajak dikarenakan zakat yang dibayarkan tersebut sesuai dengan teori kemaslahatan. Sebagaimana diketahui, secara sederhana maslahat (al-mashlahah) diartikan sebagai sesuatu yang baik atau sesuatu yang bermanfaat. Pembayaran zakat yang pada akhirnya akan mengurangi jumlah pajak akan memberikan manfaat bagi masyarakat khususnya umat muslim yang juga sebagai wajib pajak. Dengan adanya pengurangan tersebut, beban ganda yang harus ditanggung sedikitnya dapat berkurang.

Zakat disebut sebagai alat distribusi kekayaan yang berkeadilan, hal ini telah dijelaskan oleh para ulama karena :

1. Zakat menunjukkan bahwa Islam mengakui kepemilikan pribadi dan melarang memakan harta orang lain dengan jalan yang batil.

2. Islam melarang harta benda hanya beredar di kalangan orang-orang kaya saja sebagaimana terjadi dalam masyarakat barat dengan adanya peraturan bank dan perserikatan-perserikatan spekulatif yang pada akhirnya menimbulkan 
pemberontakan kaum buruh kepada kaum pemilik modal. Dengan demikian, zakat mencegah terjadinya benturan sosial. ${ }^{3}$

Hal tersebut sejalan dengan tujuan pengelolaan zakat menurut Pasal 3 Undang-Undang Nomor 23 Tahun 2011 yang menyatakan bahwa pengelolaan zakat bertujuan untuk :

a. Meningkatkan efektivitas dan efisiensi pelayanan dalam pengelolaan zakat Pengelolaan zakat yang baik akan memudahkan langkah sebuah lembaga pemungut zakat untuk mencapai tujuan inti dari zakat itu sendiri, yaitu optimalisasi zakat. Dengan bertindak efisien dan efektif, lembaga pemungut zakat mampu memanfaatkan dana zakat yang ada dengan maksimal.

b. Meningkatkan manfaat zakat untuk mewujudkan kesejahteraan masyarakat dan penanggulangan kemiskinan.

Pengelolaan zakat dimaksudkan agar dana zakat yang disalurkan benar-benar sampai pada orang yang tepat dan menyalurkan dana zakat tersebut dalam bentuk yang produktif sehingga mampu meningkatkan kesejahteraan masyarakat. Pemanfaatan zakat untuk hal yang produktif dapat dilakukan dengan mendirikan Rumah Asuh, melakukan pelatihan home industry, mendirikan sekolah gratis, dan sebagainya.

Dengan adanya kebijakan mengenai potongan pajak atas zakat yang telah dibayarkan, maka diharapkan masyarakat sebagai wajib zakat dengan sukarela membayar zakat kepada badan/lembaga yang disahkan oleh pemerintah. Dengan membayar kepada badan/lembaga yang disahkan oleh pemerintah, maka pemerintah dalam mengelola zakat untuk kemaslahatan umat.

Pemotongan pajak pribadi atas zakat yang telah dibayarkan juga telah memenuhi asas kepastian hukum. Hal ini sebagaimana diketahui bahwa dalam UU Nomor 23 Tahun 2011 tentang Pengelolaan Zakat dan UU Perpajakan maupun peraturan pelaksanaannya sudah diatur secara jelas mengenai hal tersebut. Peraturan perundang-undangan tersebut merupakan suatu ketentuan atau ketetapan hukum suatu negara yang mampu menjamin hak dan kewajiban

${ }^{3}$ Bayu Taufiq Possumah, Agar Zakat Lebih Produktif, http://www.academia.edu, (diakses 28 Desember 2014). 
setiap warga negara. Dengan adanya peraturan perundangan-undangan tersebut, pemotongan pajak pribadi atas zakat yang telah dibayarkan telah memenuhi asas kepastian hukum. Hal ini dibuktikan dengan adanya peraturan dibuat dan diundangkan secara pasti dan telah mengatur secara jelas dan logis mengenai pemotongan pajak pribadi atas zakat yang telah dibayarkan oleh muzaki.

\section{Permasalahan Yang Timbul Atas Potongan Pajak Pribadi Terhadap Zakat}

\section{Yang Telah Dibayarkan Serta Solusinya}

Beberapa permasalahan yang timbul atas peraturan mengenai pengurangan penghasilan kena pajak atas zakat yang telah dibayarkan, yaitu :

1. Kurangnya pengetahuan masyarakat terkait adanya peraturan mengenai pemotongan pajak pribadi atas zakat yang dibayarkan

Pembayaran zakat sebagai pengurang penghasilan kena pajak (penghasilan bruto) telah berlaku sejak 2001. Namun sampai saat ini masih banyak Wajib Pajak orang pribadi pemeluk agama Islam atau pembayar zakat (muzaki) yang belum memanfaatkan pengurangan penghasilan bruto atas Pajak Penghasilan $(\mathrm{PPh})$ tersebut.

Untuk mengatasi permasalahan tersebut, perlu upaya mensosialisasikan zakat sebagai pengurang penghasilan bruto. Hal ini tidak cukup hanya dilakukan oleh BAZNAS dan Kementerian Agama saja, tetapi membutuhkan koordinasi, kerjasama dan sinergi dengan instansi terkait, terutama jajaran Direktorat Jenderal Pajak. Koordinasi, kerjasama dan sinergi itulah yang ke depan perlu dibangun di tingkat institusi, karena bagi umat Islam zakat dan pajak adalah dua kewajiban yang seiring dan paralel. ${ }^{4}$

Amil zakat dan pegawai pajak di semua kantor pelayanan diharapkan dapat memberi informasi dan penjelasan kepada para muzaki dan Wajib Pajak yang dilayaninya terkait dengan adanya peraturan mengenai zakat yang dapat dikurangkan dari penghasilan bruto.

Tidak dapat dipungkiri bahwa zakat yang hanya diperhitungkan sebagai pengurang penghasilan bruto, memang belum memenuhi harapan maksimal

${ }^{4}$ Didin Hafidhuddin, Zakat sebagai Pengurang Penghasilan Kena Pajak, (http://pusat.baznas.go.id, diakses 1 Januari 2018). 
para muzaki dan lembaga zakat di tanah air. Akan tetapi, menurut kaidah fiqih, "Apa yang tidak didapat seluruhnya, jangan ditinggalkan seluruhnya." Jika kita belum berhasil memperjuangkan zakat sebagai pengurang pajak, maka zakat sebagai pengurang penghasilan kena pajak jangan disia-siakan.

2. Belum ada peraturan perundang-undangan yang mengatur mengenai sanksi apabila tidak membayar zakat

Pengelolaan zakat di Indonesia telah ditopang oleh sebuah perangkat hukum yaitu UU No.23 tahun 2011. Namun pengelolaan zakat di Indonesia hingga kini belum memberikan hasil yang optimal, baik pengumpulan maupun pemberdayaan dana zakat. Karena sampai saat ini dana zakat belum mampu memberikan pengaruh yang lebih besar bagi terwujudnya kesejahteraan umat Islam. Sebagai payung hukum dalam pengelolaan zakat di Indonesia, undang-undang tersebut tidak secara tegas merinci para Muzaki dan sanksi bagi yang tidak berzakat. Undang-undang ini hanya sebatas pengelolaan semata.

Untuk ke depannya, perlu adanya peraturan pemerintah yang mengatur mengenai pelaksanaan UU Nomor 23 Tahun 2011 tentang Pengeolaan Zakat secara menyuluruh, sehingga ada kejelasan apabila terjadi pelanggaran dalam penghitungan zakat.

Saat ini pemerintah Indonesia berencana akan memotong 2,5 persen dari gaji Pegawai Negeri Sipil (PNS) untuk membayarkan zakat. Ketentuan itu berlaku khusus PNS muslim dan akan tertuang dalam Peraturan Presiden (Perpres). Pemotongan gaji demi zakat bagi PNS muslim itu tidak bersifat mandatory (wajib), sehingga PNS Muslim yang menolak bisa mengajukan keberatan. Pemerintah berdalih landasan hukum untuk mewajibkan penghasilan PNS dipotong zakat adalah UU 23 Tahun 2011 tentang Pengelolaan Zakat, PP 14 Tahun 2014 tentang Pelaksanaan Zakat, Inpres 3 Tahun 2014 tentang Optimalisasi Pengumpulan Zakat dan Permenag 52 Tahun 2014 tentang Syarat dan Tata Cara Perhitungan Zakat Mal dan Zakat Fitrah. 
Wacana pemerintah memungut zakat dari aparatur sipil negara (ASN) beragama Islam mengundang polemik karena menimbulkan pro dan kontra. Pihak PNS sendiri ada yang setuju dan ada yang keberatan. Sementara pihak MUI setuju bahwa potensi zakat harus lebih dioptimalkan dan dimanfaatkan untuk sebesar-besarnya kemaslahan umat Islam. Namun MUI mengharapkan dalam pelaksanaannya harus melalui sebuah perencanaan yang baik, kesiapan institusi zakat yang profesional, kapabel dan akuntabel. Selain itu, harus melibatkan para pihak yang memiliki kepentingan terhadap zakat. Sehingga dalam pelaksanaannya mendapat dukungan dan kepercayaan dari umat Islam serta sesuai dengan prinsip-prinsip syariah.

\section{E. PENUTUP}

Kedudukan potongan pajak pribadi terhadap zakat yang telah dibayarkan berdasarkan UU Nomor 23 Tahun 2011 tentang Pengelolaan Zakat adalah bahwa zakat yang telah dibayarkan akan mengurangi penghasilan bruto atas pajak pribadi. Artinya, zakat tidak mengurangi nominal pajak pribadi, tetapi dalam perhitungannya, zakan akan dikurangkan dari penghasilan bruto sehinga dalam hal ini zakan akan mengurangi penghasilan kena pajak (PKP). Syarat tersebut antara lain melampirkan bukti pembayaran zakat dan pembayaran zakat dilakukan kepada badan/lembaga amil zakat yang disahkan oleh pemerintah.

Permasalahan yang timbul atas potongan pajak pribadi terhadap zakat yang telah dibayarkan adalah masih kurangnya pengetahuan masyarakat terkait adanya peraturan mengenai pemotongan pajak pribadi atas zakat yang dibayarkan. Hal ini dikarenakan kurangnya sosialisasi mengenai peraturan tersebut terhadap masyarakat. Untuk mengatasi permasalahan tersebut, perlu upaya mensosialisasikan mengenai zakat sebagai pengurang penghasilan bruto yang dilakukan secara terintegrasi bagi dari lembaga keagamaan maupun lembaga perpajakan. Permasalahan lainnya adalah belum ada peraturan perundangundangan yang mengatur mengenai sanksi apabila tidak membayar zakat. Untuk mengatasi permasalahan tersebut untuk ke depannya, perlu adanya peraturan pemerintah yang mengatur mengenai pelaksanaan UU Nomor 23 Tahun 2011 
tentang Pengeolaan Zakat secara menyuluruh, sehingga ada kejelasan apabila terjadi pelanggaran dalam penghitungan zakat.

\section{DAFTAR PUSTAKA}

\section{Buku}

Aji Damanuri, Pendayagunaan Zakat Studi Implikasi Hukum Zakat Terhadap Pemberdayaan Mustahik di Lembaga Amil Zakat Infaq dan Shadaqah Muhammadiyah, (http://hmipositive.blogspot.com, diakses 20 Januari 2015).

\section{Jurnal}

Abdul Aziz, Pendayagunaan Zakat Sebagai Upaya Pengentasan Kemiskinan, Jurnal Ius Constituendum Vol 1 No 1, Magister Hukum Universitas Semarang, 2016, Semarang. http://dx.doi.org/10.26623/jic.v1i2.552

Sri Andriani, Zakat sebagai Pengurang Pajak Penghasilan Pada Badan Amil Zakat, JRAK, Vol. 4 No.1 Februari 2013

\section{Peraturan perundang-undangan}

Undang-Undang Dasar Negara Republik Indonesia Tahun 1945. Undang-Undang Nomor 23 Tahun 2011 tentang Pengelolaan Zakat. Undang-Undang Nomor 36 Tahun 2008 tentang Pajak Penghasilan.

Peraturan Direktur Jenderal Pajak Nomor PER-6/PJ/2011 tentang Pelaksanaan Pembayaran Dan Pembuatan Bukti Pembayaran Atas Zakat Atau Sumbangan Keagamaan Yang Sifatnya Wajib Yang Dapat Dikurangkan Dari Penghasilan Bruto

Peraturan Pemerintah Nomor 18 Tahun 2009 tentang Bantuan atau Sumbangan

Keagamaan yang Sifatnya Wajib yang Dikecualikan dari Objek Pajak Penghasilan

Keputusan Presiden Nomor 8 Tahun 2001 tentang Badan Amil Zakat Nasional Peraturan Menteri Keuangan Nomor 254/PMK.03/2010 tentang Tata Cara Pembebanan Zakat atau Sumbangan Keagamaan yang Sifatnya Wajib yang dapat Dikurangkan dari Penghasilan Bruto

Peraturan Direktur Jenderal Pajak Nomor PER-11/PJ/2017 tentang Badan/Lembaga yang Dibentuk atau Disahkan oleh Pemerintah yang Ditetapkan sebagai Penerima Zakat atau Sumbangan Keagamaan yang Sifatnya Wajib yang Dapat Dikurangkan dari Penghasilan Bruto

Peraturan Direktur Jenderal Pajak Nomor PER-6/PJ/2011 tentang Pelaksanaan Pembayaran dan Pembuatan Bukti Pembayaran Atas Zakat

\section{Website}


Bayu Taufiq Possumah, Agar Zakat Lebih Produktif, http://www.academia.edu, (diakses 28 Desember 2014).

Didin Hafidhuddin, Zakat sebagai Pengurang Penghasilan Kena Pajak, (http://pusat.baznas.go.id, diakses 1 Januari 2018).

“Menjadi Wajib Zakat atau Wajib Pajak Dulu ?”, (https://www.kompasiana.com, diakses 10 November 2017). 